\title{
Reactivity of alkyl aryl selenides towards butyllithiums: synthesis and alkylation of aryllithiums; a new synthetic route to aryl alkanes
}

\author{
Alain Krief, ${ }^{* a}$ Willy Dumont, ${ }^{\text {a }}$ and Frédéric Gillin ${ }^{\text {a,b }}$ \\ ${ }^{a}$ Laboratoire de Chimie Organique de Synthèse, Facultés Universitaires N.-D. de la Paix, 61 rue \\ de Bruxelles, Namur, B-5000, Belgium. \\ ${ }^{b}$ Fonds pour la Formation à la Recherche dans l'Industrie et l'Agriculture, 5 rue d'Egmont, \\ Bruxelles B-1000, Belgium \\ E-mail: alain.krief@fundp.ac.be
}

\begin{abstract}
Dedicated to Professor Atta-ur-Rahman, at the occasion of his 65 birthday for his dedication to chemistry, especially for his contribution to the development of research and education for the young from third world countries
\end{abstract}

\begin{abstract}
This paper reports original results concerning the $\mathrm{Se} / \mathrm{Li}$ exchange reaction involving the cleavage of the C-Se bond of aryl alkyl selenides by butyllithiums. This reaction is one of the methods available to produce functionalized organolithium compounds.
\end{abstract}

Keywords: Selenides, alkyllithiums, aryllithiums, solvent effects, C-Se bond cleavage, Se/Li exchange reaction

\section{Introduction}

Organolithium compounds, the "Gilman reagents", have found wide application in organic synthesis. ${ }^{1 \mathrm{a}-\mathrm{g}}$ They are easily accessible, possess a wide range of reactivity which at several occasions surpass that of their organomagnesium competitors, the "Grignard reagents". ${ }^{2}$ They are more reactive, possess a greater aptitude (i) to perform metallation reactions (hydrogen/lithium exchange) (ii) to add to unactivated C,C double bonds and (iii) to add 1,2 to enones. ${ }^{1 \mathrm{~h}}$

The two former reactions proved to be extremely valuable for the synthesis of other organolithiums which can be also produced by halogen/lithium-, metalloid/lithium- and metal/lithium exchange reactions. ${ }^{1 \mathrm{a}-\mathrm{g}}$ Organolithium compounds are also valuable precursors of high order cuprates and lithium amides. ${ }^{\text {la-g }}$ 
Their synthesis from organic halides is however usually far less efficient than that of related Grignard reagents due to the inherent reactivity of lithium and the high propensity of alkyllithiums to metallate ethers in which they are usually prepared. ${ }^{1 \mathrm{a}-\mathrm{g}}$

We report in this paper our detailed work on the synthesis of aryllithium compounds from related selenides which involve the selenium/lithium ( $\mathrm{Se} / \mathrm{Li}$ )-exchange reaction.

This reaction, first reported by Gilman on phenyl methyl selenide and n-butyllithium was found to proceed quite sluggishly in refluxing ether. It produces, through the intermediate formation of phenyllithium (or its butyl methyl selenide complex), benzoic acid in modest yield $(20 \%)$ after quite a long reaction time and sequential carboxylation and acid hydrolysis (Scheme 1 , entry a). ${ }^{3} \mathrm{We}$ found in the mid-seventies that this reaction, is faster and much more efficient, if performed in THF (Scheme 1, entry b). ${ }^{4}$

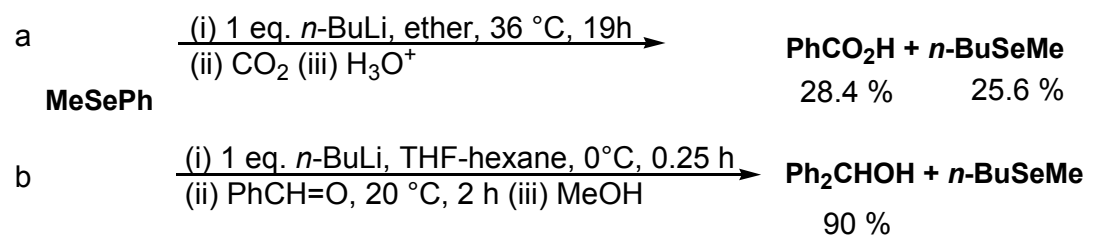

\section{Scheme 1}

The cleavage of the C-Se bond in functionalized selenides pioneered by Seebach, ${ }^{5}$ has been then successfully extended to the synthesis of $\alpha$-selenoalkyllithiums, ${ }^{4-6} \alpha, \alpha$-diselenoalkyl lithiums, ${ }^{5-7} \alpha$-silylalkyllithiums, ${ }^{8}$ allyl- ${ }^{9}$ and benzyl- ${ }^{10}$ lithiums from selenoacetals, selenoorthoesters, $\alpha$-silylalkylselenides and allyl- and benzyl-selenides respectively (Scheme 2). It has been also established that vinyl phenyl selenide chemoselectively leads to phenyllithium and vinyl alkyl selenides. ${ }^{11}$
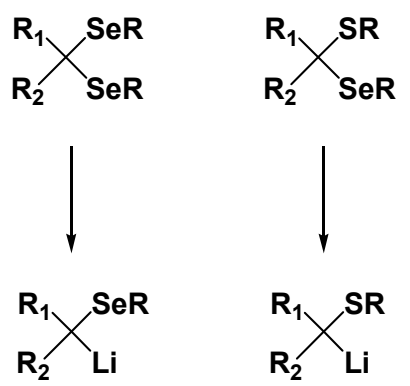
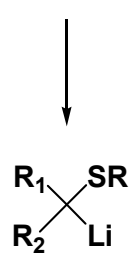
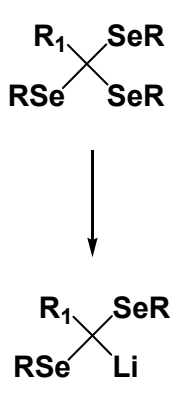
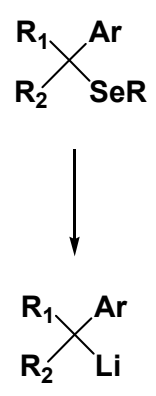
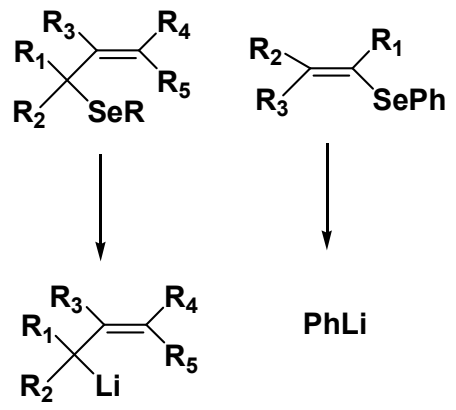

PhLi

\section{Scheme 2}

Although limited to the cases reported above, the selenium/lithium exchange offers the advantage $^{6}$ (i) to take place in an homogeneous solution, (ii) to proceed faster in THF than in ether $^{4}$ (iii) to be highly chemoselective even with benzaldehyde selenoacetals which were expected to be more prone for competing metallation reaction, (iv) to generate the 
organometallic whose carbanion is expected to be the most stabilized, (v) to produce concomitantly a novel selenide (usually butyl selenide) which is inert towards any of the organolithiums $^{6}$ used or generated in the process. In many cases reported above, the selenium/lithium exchange proved to be the only method available to produce organolithiums and in the case of allyl- and benzyllithiums the method of choice for their synthesis.

\section{Results and Discussion}

We report some specific examples which delineate the scope and limitation of the seleniumlithium exchange reaction between alkyllithiums and a series of alkyl phenyl selenides, producing dialkyl selenides and aryllithiums. We have particularly compared the reactivity of a series of alkyl phenyl selenides and alkyllithiums whose tetragonal carbon attached to the selenium or/and the lithium atom is increasingly substituted by alkyl groups.

We have also compared the aptitude of alkyllithiums to cleave chemoselectively the C-Se bond of a series of butyl aryl selenides whose phenyl group is substituted by electron withdrawing or releasing groups.

\section{Effect of the solvent}

In our earlier work, we described that methyl phenyl selenide, reacts faster with $n$-butyllithium when the reaction is conducted in THF rather than in ether. ${ }^{4}$ We have now confirmed this tendency on performing the reaction on $n$-butyl phenyl selenide using sec-butyllithium instead of n-butyllithium (Scheme 3).

$n$-BuSePh + s-Bu-Li $\frac{\text { solvent, }}{\mathrm{T}^{\circ} \mathrm{C}, 1 \mathrm{~h}}[n$-BuSes-Bu $+\mathrm{PhLi}] \stackrel{\mathrm{MeOH}, \mathrm{T}^{\circ} \mathrm{C}}{\longrightarrow} n$-BuSes-Bu + PhH+ MeOLi

\begin{tabular}{|c|c|c|c|c|c|}
\hline \multicolumn{2}{|c|}{} & \multicolumn{2}{|c|}{$\mathrm{T}=-78^{\circ} \mathrm{C}$} & \multicolumn{2}{c|}{$\mathrm{T}=-25^{\circ} \mathrm{C}$} \\
\hline Entry & Solvent & $n$-BuSes-Bu (\%) & $n$-BuSePh (\%) & n-BuSes-Bu (\%) & $n$-BuSePh (\%) \\
\hline a & THF & $84^{*}$ & $12^{*}$ & 86 & 0 \\
\hline b & Ether & 0 & 94 & $53^{*}$ & $40^{*}$ \\
\hline c & Pentane & 0 & 89 & 0 & 92 \\
\hline
\end{tabular}

Percentage estimated by ${ }^{1} \mathrm{H}-\mathrm{NMR}$ of the crude mixture

\section{Scheme 3}

For that purpose, we have systematically reacted at $-78{ }^{\circ} \mathrm{C}$ and at $-25{ }^{\circ} \mathrm{C}$, the two partners and have quenched, after one hour, the medium with precooled methanol. 
The reaction proceeds quite efficiently in one hour at $-78{ }^{\circ} \mathrm{C}$ in $\mathrm{THF}$ but does not reach completion. It is however completely achieved if instead performed at $-25^{\circ} \mathrm{C}$ in the same solvent (Scheme 3, entry a). We have also observed an important difference of reactivity between THF and ether since butyl phenyl selenide does not react in the later solvent at $-78^{\circ} \mathrm{C}$ and is only partially cleaved when the reaction is carried out $-25^{\circ} \mathrm{C}$ (Scheme 3 , compare entries a and b). Finally, we have not been able to cleave the C-Se bond using pentane as the solvent (Scheme 3, compare entry c to entries $\mathrm{a}, \mathrm{b})$.

\section{Role of the organolithium reagents}

We have observed that sec-butyllithium is the most reactive organolithium among the series $(n$ BuLi, sec-BuLi, tert-BuLi), towards alkyl phenyl selenides. For that purpose we have performed on three alkyl phenyl selenides, possessing a side chain of increasing length ( $\mathrm{Me}, n$-Bu, $n$-Dec), competing experiments involving a ten fold excess of an equimolar mixture of $n$-BuLi, sec-BuLi, tert-BuLi. We obtained, after methanolysis, benzene arising from the protonation of the first formed phenyllithium and a series of butyl selenides resulting from the phenyl/butyl exchange. In all the cases, the $n$-butyl selenide was missing whereas $s$-butyl selenide largely predominates over the tertiary one (Scheme 4).

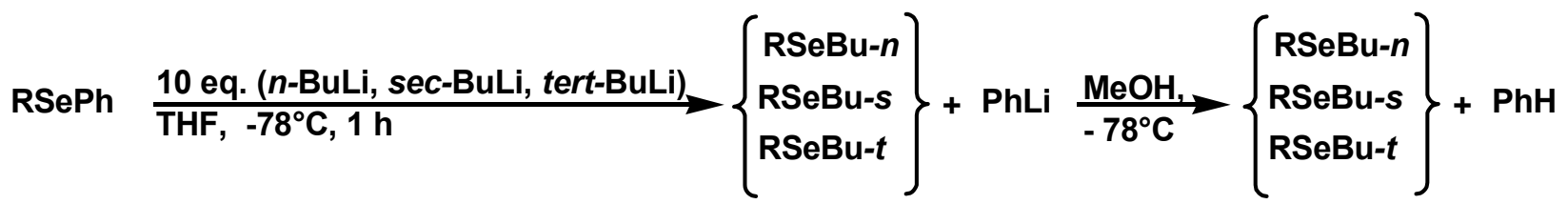

\begin{tabular}{|c|c|c|c|c|}
\hline Entry & $\mathrm{R}$ & $n$-BuSeR $(\%)$ & sec-BuSeR $(\%)$ & tert-BuSeR $(\%)$ \\
\hline $\mathbf{a}$ & $\mathrm{Me}$ & 0 & $56^{*}$ & $36^{*}$ \\
\hline $\mathbf{b}$ & $n$-Bu & 0 & $78^{*}$ & $12^{*}$ \\
\hline $\mathbf{c}$ & $n$-Dec & 0 & $76^{* *}$ & $10^{* *}$ \\
\hline
\end{tabular}

Percentage estimated by:* GC using as internal standard, ${ }^{* *} \mathrm{H}-\mathrm{NMR}$ of the crude mixture

\section{Scheme 4}

This can be rationalized taking into account a subtle balance between steric and electronic effects on the carbanionic center. It is interesting to notice that the lowest chemoselectivity is observed with the selenide possessing the smallest alkyl substituent (Scheme 4, entry a, compare to entries b,c; relative selectivity : $\mathrm{Me} / \mathrm{Bu} / \mathrm{Dec}: 22 / 73 / 76)$.

We have also checked the intrinsic reactivity of methyllithium and each of the isomers of butyllithiums used separately towards $n$-butyl phenyl selenide used as a model. Those organolithiums possess an increasing alkyl substitution at their carbonic center (Scheme 5, compare entries a,d,g). 
Methyllithium is inert towards $n$-butyl phenyl selenide even when the reaction is performed at room temperature for one hour.

The whole family of butyllithiums however cleaves the C-Se bond of $n$-butyl phenyl selenide at $0{ }^{\circ} \mathrm{C}$. We have confirmed that $s e c-\mathrm{BuLi}$ is the most reactive since it is the only one able to react reasonably efficiently in $1 \mathrm{~h}$ at $-78^{\circ} \mathrm{C}$ with $n$-butyl phenyl selenide (Scheme 5, entry $\mathrm{d}$, compare to entries a and $\mathrm{g}$ ).

$\mathrm{RSePh} \stackrel{\mathrm{R}_{1} \mathrm{Li}, \mathrm{THF}, \mathrm{T}^{\circ} \mathrm{C}, 1 \mathrm{~h}}{\longrightarrow}\left[\mathrm{RSeR}_{\mathbf{1}}+\mathrm{PhLi}\right] \stackrel{\mathrm{MeOH}, \mathrm{T}^{\circ} \mathrm{C}}{\longrightarrow} \mathrm{RSeR}_{\mathbf{1}}+\mathbf{P h H}$

\begin{tabular}{|c|c|c|c|c|c|c|}
\hline \multicolumn{2}{|c|}{} & \multicolumn{2}{c|}{$\mathrm{T}=-78^{\circ} \mathrm{C}$} & \multicolumn{2}{c|}{$\mathrm{T}=0{ }^{\circ} \mathrm{C}$} \\
\hline Entry & $\mathrm{R}$ & $\mathrm{R}_{1}$ & $\mathrm{BuSeR}_{1}(\%)$ & $\mathrm{BuSePh}(\%)$ & $\mathrm{BuSeR}_{1}(\%)$ & $\mathrm{BuSePh}(\%)$ \\
\hline $\mathbf{a}$ & $n$ - $\mathrm{Bu}$ & $n-\mathrm{Bu}$ & $23^{*}$ & $71^{*}$ & 88 & 0 \\
\hline $\mathbf{b}$ & $s-\mathrm{Bu}$ & $n-\mathrm{Bu}$ & 0 & 90 & $24^{*}$ & $72^{*}$ \\
\hline $\mathbf{c}$ & $t-\mathrm{Bu}$ & $n-\mathrm{Bu}$ & 0 & 89 & 0 & 93 \\
\hline $\mathbf{d}$ & $n-\mathrm{Bu}$ & $s-\mathrm{Bu}$ & $84^{*}$ & $12^{*}$ & 90 & 0 \\
\hline $\mathbf{e}$ & $s-\mathrm{Bu}$ & $s-\mathrm{Bu}$ & $6^{*}$ & $92^{*}$ & $39^{*}$ & $55^{*}$ \\
\hline $\mathbf{f}$ & $t-\mathrm{Bu}$ & $s-\mathrm{Bu}$ & 0 & 87 & 0 & 95 \\
\hline $\mathbf{g}$ & $n-\mathrm{Bu}$ & $t-\mathrm{Bu}$ & $32^{*}$ & $65^{*}$ & 90 & 0 \\
\hline $\mathbf{h}$ & $s-\mathrm{Bu}$ & $t-\mathrm{Bu}$ & 0 & 89 & $36^{*}$ & $61^{*}$ \\
\hline $\mathbf{i}$ & $t-\mathrm{Bu}$ & $t$-Bu & 0 & 89 & 0 & 90 \\
\hline
\end{tabular}

* Percentage estimated by ${ }^{1} \mathrm{H}-\mathrm{NMR}$ of the crude mixture

\section{Scheme 5}

We have also observed that the whole series of butyllithiums ( $n-$, sec-, tert-Bu) poorly reacts with sec-butyl phenyl selenide (Scheme 5, entries b,e,h) and is inert towards tert-butyl phenyl selenide (Scheme 5, entries c, f, i).

\section{About the structure of the aryl alkyl selenide}

\section{a. Effect of the alkyl chain}

We observed a very big difference of reactivity, towards $n$-butyllithium, of the members of the family of $(n, s, t)$-butyl phenyl selenides whose carbon atom directly attached to the selenium atom is differently alkyl substituted.

Increasing alkyl substitution dramatically lowers the aptitude of $n$-butyllithium to produce phenyllithium by C-Se bond cleavage (Scheme 5, compare entries a,b and c): Thus whereas $n$ butyl phenyl selenide is quantitatively cleaved at $0{ }^{\circ} \mathrm{C}$ in THF by $n$-butyllithium, to produce di $n$ - 
butyl selenide in $88 \%$ yield ( $1 \mathrm{~h}$, Scheme 5, entry a) its s-butyl isomer is poorly reactive and leads to dibutyl selenide in $24 \%$ yield ( $1 \mathrm{~h}$, Scheme 5, entry b) and tert-butyl phenyl selenide is recovered unchanged under the same conditions (Scheme 5, entry c).

\section{b. Effect of the aryl group}

Last but not least, we have compared the reactivity towards $n$-butyllithium (THF, $-78^{\circ} \mathrm{C}, 1 \mathrm{~h}$ ), of a series of aryl methyl selenides variously substituted on the aromatic ring. For that purpose, we have reacted at $-78{ }^{\circ} \mathrm{C}$ in THF, $n$-butyllithium and a five fold excess of equimolar amounts of methyl phenyl and aryl methyl selenides. We have compared by gas chromatography the ratio of benzene and arene resulting from methanolysis of the corresponding organolithium intermediates (Scheme 6). We have at the same time secured that the aryllithium as well as $n$-butyl methyl selenide, formed concomitantly, are produced in at least $80 \%$ yield.

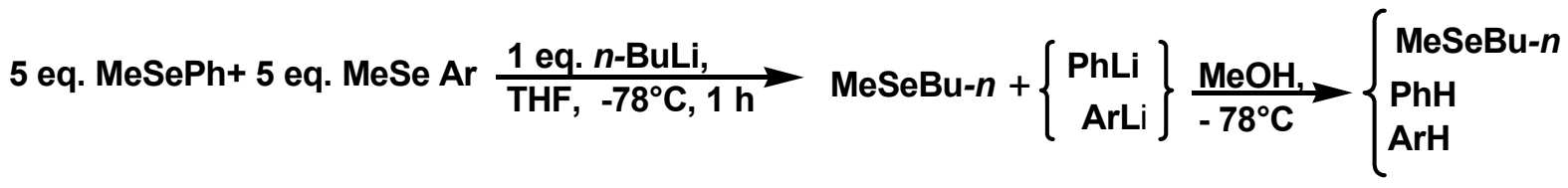

\begin{tabular}{|c|c|c|c|c|}
\hline Entry & $\mathrm{Ar}$ & $\mathrm{PhH}^{*}(\%)$ & $\mathrm{ArH}^{*}(\%)$ & $\mathrm{PhH} /$ ArH ratio \\
\hline a & $o-\mathrm{MeOPh}-$ & 45 & 45 & $50 / 50$ \\
\hline b & $m$-MeOPh- & 31 & 52 & $37 / 63$ \\
\hline c & $p-\mathrm{MeOPh}-$ & 76 & 17 & $82 / 18$ \\
\hline d & $p$ - $\mathrm{Me}_{2} \mathrm{NPh}-$ & 95 & 0 & $100 / 0$ \\
\hline e & $p$ - $\mathrm{CF}_{3} \mathrm{Ph}-$ & 0 & 94 & $0 / 100$ \\
\hline
\end{tabular}

* Determined by gas chromatography using an internal standard

\section{Scheme 6}

The presence of an electron-withdrawing substituent such as the trifluoromethyl group in para-position or to a lower extend a methoxy group in meta-position favors the formation of the corresponding aryllithiums (Scheme 6, entries e,b) whereas electron-donating substituents such as $p$-methoxy- or $p$-dimethylamino substituents disfavors the reaction (Scheme 6, entries c,d). In that context, the propensity of methyl $o$-methoxy-phenyl selenide to produce $o$ methoxyphenyllithium, although it possesses an electron-donating group in ortho-position, might be attributed to its chelating properties of the ortho-methoxy group (Scheme 6, entry a). Related behavior named ortho-lithiation or directed metallation, has been already used to explain the selective metallation of methoxy benzene in ortho-position using $n$-butyllitium. ${ }^{\text {a, } 12 \mathrm{a}-\mathrm{h}}$

We have used these observations to devise a novel efficient synthesis of aryllithiums bearing electron withdrawing or electron donating substituents on the aromatic ring. ${ }^{1,3 a, 12,13}$ The reactions have been carried in THF on the corresponding aryl methyl selenides using a solution 
of $s$-butyllithium in cyclohexane, thus as estimated from the above result in the best solvent, with the more reactive family of selenides and the most efficient organolithium (Scheme 7).

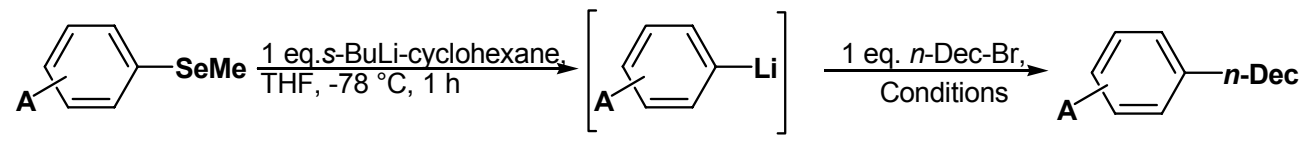

\begin{tabular}{|c|c|c|c|}
\hline Entry & $\mathrm{R}$ & Conditions & Aryl decanes $(\%) *$ \\
\hline a & $m-\mathrm{MeO}$ & $\mathrm{THF}, 0-25^{\circ} \mathrm{C}, 10 \mathrm{~h}$ & 73 \\
\hline b & $p-\mathrm{MeO}$ & $\mathrm{THF}, 0-25^{\circ} \mathrm{C}, 10 \mathrm{~h}$ & 70 \\
\hline c & $p-\mathrm{Me}_{2} \mathrm{~N}$ & $\mathrm{THF}, 0-25^{\circ} \mathrm{C}, 10 \mathrm{~h}$ & 61 \\
\hline d & $p-\mathrm{CF}_{3}$ & $\mathrm{THF}, 0-25^{\circ} \mathrm{C}, 10 \mathrm{~h}$ & 33 \\
\hline e & $p-\mathrm{CF}_{3}$ & 1 eq. $\mathrm{HMPA},-78,1 \mathrm{~h} ; 0-25^{\circ} \mathrm{C}, 10 \mathrm{~h}$ & 64 \\
\hline
\end{tabular}

* Refers to the yield of isolated pure compounds

\section{Scheme 7}

The reaction efficiently occurs in all the cases in less than one hour at $-78{ }^{\circ} \mathrm{C}$ and provides, in almost quantitative yields, the whole series of aryllithiums bearing electron-withdrawing as well as donating groups attached to the aromatic ring (Scheme 7).

Alkylation of those aryllithiums with decyl bromide only takes place around $0{ }^{\circ} \mathrm{C}$ and produces, except for $p$-trifluoromethyl-phenyllithium (Scheme 7, entry d), 1-aryl-decanes in 60$70 \%$ yield (Scheme 7, entries a-c). We found that the alkylation of $p$-trifluoromethylphenyllithium can be achieved in much better yield in the presence of HMPA (Scheme 7, entry e; compare to entry d).

This synthesis of aryllithiums offers advantages over the related one involving the Chalogen bond cleavage of aryl halides by the same reagents. ${ }^{13}$

Indeed, these processes concomitantly generate respectively methyl butyl selenide or butyl halide as by-product but whereas the former is inert, the later is prone to react with aryllithiums, $n$-BuLi or sec-BuLi. Therefore, a mixture of aryl alkanes is produced after addition of a different alkyl halide to the reaction medium unless special tricks are used such as performing the halogen/metal exchange with 2 equivalent of tert-BuLi. ${ }^{13 \mathrm{~d}}$

In conclusion, alkyl aryl selenides produce aryllithiums when reacted with butyllithiums. The reaction is more efficient with methyl selenides and more difficult when the alkyl chain is longer or branched. $s$-Butyllithium proved to be the best reagent among the series of butyllithiums and THF the best solvent. Work is in progress to determine the scope of this reaction as well as that of the alkylation of the aryllithiums produced. 


\section{Experimental Section}

General Procedures. Alkyllithium reagents have been purshased from Sigma Aldrich : $n$ butyllithium, 1.6 M solution in hexanes; $s$-butyllithium, $1.4 \mathrm{M}$ solution in cyclohexane; $t$ butyllithium, 1.7 $\mathrm{M}$ solution in pentane; methyllithium, 1.6 $\mathrm{M}$ solution in diethyl ether. Concentrations of the alkyllithium reagents were determined using the Suffert's method. ${ }^{14}$

${ }^{1} \mathrm{H},{ }^{13} \mathrm{C}$ and ${ }^{77} \mathrm{Se}$ NMR spectra were recorded at $20^{\circ} \mathrm{C}$ in $\mathrm{CDCl}_{3}$ on a $400 \mathrm{MHz}$ Jeol Spectrometer (Jeol JNM EX-400). Chemical shifts are reported in $\delta$ ppm relative to tetramethylsilane (TMS) as a singlet at $\delta=0$ for ${ }^{1} \mathrm{H}$ NMR spectra or $\mathrm{CDCl}_{3}$ as a triplet at $\delta=77$ for ${ }^{13} \mathrm{C}$ NMR spectra. Infrared spectra were recorded on a BIO-RAD FTS-165 spectrometer and are reported in wave numbers between 4000 and $600 \mathrm{~cm}^{-1}$. Liquid samples were prepared as a film between two sodium chloride cells. Mass spectra were recorded on a Hewlett-Packard 5989B mass spectrometer equipped with a Hewlett-Packard 5890 series II gas chromatograph. Elemental analyses were carried out at the "centre régional de Microanalyse de l'université Pierre et Marie Curie à Paris VI" and at the "laboratoire de pharmacie des facultés universitaires Notre-Dame de la Paix". Gas chromatography analyses were performed on a Hewlett-Packard 5890A equipped with a capillary column RSL-150 or AT-Q heliflex (from Alltech), a Flam Ionization Detector warmed to $250^{\circ} \mathrm{C}$ (in a mixture of hydrogen and air) and an injector heated to $250^{\circ} \mathrm{C}$. The carrier gas was helium at a pressure of $1 \mathrm{ml} / \mathrm{min}$. Thin-Layer Chromatography (TLC) was performed on aluminum supported $0.25 \mathrm{~mm}$ silica gel plates (Merck 5719, 250 meshes). Visualization of TLC plates was accomplished with one or more of the following techniques : $254 \mathrm{~nm}$ UV light, $10 \%$ phosphomolybdic acid in ethanol. Solvents were dried prior to their uses and commercially available chemicals were used without further purification.

General procedure for reactions involving butyl phenyl selenides and butyllithiums (Schemes 3 and 5). A solution of alkyllithium $(1.03 \mathrm{mmol})$ is added dropwise to a stirred solution of butyl phenyl selenide $(213 \mathrm{mg}, 1 \mathrm{mmol})$ in the solvent specified in the Scheme 3 and Scheme $5(1 \mathrm{~mL})$ maintained at $-78^{\circ} \mathrm{C}$ under an atmosphere of argon,. The mixture is stirred at $78^{\circ} \mathrm{C}$ for $1 \mathrm{~h}$ then quenched with methanol $(2 \mathrm{~mL})$. Water $(5 \mathrm{~mL})$ is added and the organic layer is separated. The aqueous layer is extracted with diethyl ether $(3 \times 50 \mathrm{~mL})$. The combined organic layers are washed with water $(5 \mathrm{~mL})$, dried over magnesium sulfate, filtrated and concentrated under reduced pressure using a rotary evaporator. The crude mixture has been analyzed by ${ }^{1} \mathrm{H}$ NMR and compared to authentic samples. In some cases, the pure product has been isolated. The full spectroscopic data is described below:

$n$-butyl phenyl selenide. ${ }^{15}$ yellow liquid; $\mathrm{R}_{\mathrm{f}}=0.6$ (pentane $100 \%$ ); IR (neat, $\mathrm{cm}^{-1}$ ): 3072, 3060, 2959, 2930, 2872, 1949, 1864, 1791, 1580, 1477, 1462, 1437, 1379, 1296, 1259, 1200, 1072, 1023, 999, 900, 735, 690, 670; ${ }^{1} \mathrm{H}-\mathrm{NMR}\left(\mathrm{CDCl}_{3}, 400 \mathrm{MHz}\right): \delta=0.91\left(\mathrm{t}, J=7.5 \mathrm{~Hz}, 3 \mathrm{H}, \mathrm{C}_{3}\right)$, 1.43 (sex, $J=7.5 \mathrm{~Hz}, 2 \mathrm{H}, \underline{\mathrm{C}}_{2} \mathrm{CH}_{3}$ ), 1.68 (quint, $J=7.5 \mathrm{~Hz}, 2 \mathrm{H}, \mathrm{CH}_{2} \underline{\mathrm{C}}_{2} \mathrm{CH}_{2}$ ), 2.91 (t, $J=7.5$ $\left.\mathrm{Hz}, 2 \mathrm{H}, \underline{\mathrm{C}}_{2} \mathrm{Se}\right), 7.24$ (m, $3 \mathrm{H}$, ortho et para), 7.48 (m, $2 \mathrm{H}$, meta); ${ }^{13} \mathrm{C}-\mathrm{NMR}\left(\mathrm{CDCl}_{3}, 100.4\right.$ MHz): $\delta=13.47,22.85,27.52,32.18,126.61,129.01,130.71,132.40$; GC-EIMS [m/z, (\%)]: $214\left(\mathrm{M}^{+}, 36\right), 158$ (100), 154 (22), 117 (8), 91 (20), 78 (61), 51 (22) 
s-butyl phenyl selenide. Yellow liquid; $R_{\mathrm{f}}=0.65$ (pentane $100 \%$ ); IR (neat, $\mathrm{cm}^{-1}$ ): 3072, 3058, 2965, 2920, 2874, 1947, 1872, 1802, 1580, 1477, 1454, 1438, 1377, 1289, 1274, 1201, 1141, 1072, 1044, 1023, 1000, 954, 841, 787, 738, 692, 671; ${ }^{1} \mathrm{H}-\mathrm{NMR}\left(\mathrm{CDCl}_{3}, 400 \mathrm{MHz}\right): \delta=1.00(\mathrm{t}$, $\left.J=7.2 \mathrm{~Hz}, 3 \mathrm{H}, \mathrm{CH}_{2} \mathrm{CH}_{3}\right) ; 1.40\left(\mathrm{~d}, J=6.8 \mathrm{~Hz}, 3 \mathrm{H}, \mathrm{CHCH}_{3}\right), 1.61\left(\mathrm{~m}, 1 \mathrm{H}, \mathrm{CH}_{2} \mathrm{CH}_{3}\right), 1.71(\mathrm{~m}, 1$ $\left.\mathrm{H}, \underline{\mathrm{CH}}_{2} \mathrm{CH}_{3}\right), 3.24$ (sex, $\left.J=6.8 \mathrm{~Hz}, 1 \mathrm{H}, \mathrm{CHCH}_{3}\right), 7.26(\mathrm{~m}, 3 \mathrm{H}$, ortho and para), 7.54 (m, $2 \mathrm{H}$, meta); ${ }^{13} \mathrm{C}-\mathrm{NMR}\left(\mathrm{CDCl}_{3}, 100.4 \mathrm{MHz}\right): \delta=12.21,21.49,30.35,41.46,127.27,128.88,129.53$, 134.89; ${ }^{77} \mathrm{Se}-\mathrm{NMR}\left(\mathrm{CDCl}_{3}, 76.1 \mathrm{MHz}\right): \delta=397.84$; GC-EIMS [m/z, (\%)]: $214\left(\mathrm{M}^{+}, 25\right), 158$ (100), 154 (23), 117 (9), 105 (7), 78 (68), 51 (23); Anal. Calcd for $\mathrm{C}_{10} \mathrm{H}_{14} \mathrm{Se}$ : C, 56.34; H, 6.62; Found: C, 56.25; H, 6.55

t-butyl phenyl selenide. ${ }^{16}$ Yellow liquid; $\mathrm{R}_{\mathrm{f}}=0.5$ (pentane $100 \%$ ); IR (neat, $\mathrm{cm}^{-1}$ ): 3071, 3058, 3016, 2970, 2957, 2935, 2918, 2889, 2858, 2773, 2715, 1951, 1881, 1808, 1731, 1657, 1577, $1475,1456,1437,1390,1364,1326,1301,1261,1218,1153,1065,1022,1000,914,803,739$, 693, 671, 612; ${ }^{1} \mathrm{H}-\mathrm{NMR}\left(\mathrm{CDCl}_{3}, 400 \mathrm{MHz}\right): \delta=1.41\left(\mathrm{~s}, 9 \mathrm{H},\left(\mathrm{C}_{3}\right)_{3} \mathrm{C}\right), 7.31(\mathrm{~m}, 3 \mathrm{H}$, ortho and para), 7.64 (m, $2 \mathrm{H}$, meta); ${ }^{13} \mathrm{C}-\mathrm{NMR}\left(\mathrm{CDCl}_{3}, 100.4 \mathrm{MHz}\right): \delta=32.11,43.09,128.38,128.47$, 128.63, 128.24; ${ }^{77} \mathrm{Se}-\mathrm{NMR}\left(\mathrm{CDCl}_{3}, 76.1 \mathrm{MHz}\right) \delta=525.08$; GC-EIMS [m/z, $\left.(\%)\right]: 214\left(\mathrm{M}^{+}, 14\right)$, 158 (61), 78 (40), 57 (100), 51 (17).

di-n-butylselenide. ${ }^{17}$ Colorless liquid; $\mathrm{R}_{\mathrm{f}}=0.69$ (pentane $100 \%$ ); IR (neat, $\mathrm{cm}^{-1}$ ): 2958, 2928, 2872, 2730, 1668, 1464, 1378, 1292, 1258, 1195, 1090, 899, 738; ${ }^{1} \mathrm{H}-\mathrm{NMR}\left(\mathrm{CDCl}_{3}, 400 \mathrm{MHz}\right)$ : $\delta=0.93\left(\mathrm{t}, J=7.2 \mathrm{~Hz}, 6 \mathrm{H}, 2 \times \mathrm{CH}_{3}\right), 1.41\left(\mathrm{sex}, J=7.2 \mathrm{~Hz}, 4 \mathrm{H}, 2 \times \mathrm{CH}_{3} \underline{\mathrm{CH}}_{2}\right), 1.64$ (quint, $J=$ $\left.7.2 \mathrm{~Hz}, 4 \mathrm{H}, 2 \times \mathrm{CH}_{2} \mathrm{CH}_{2} \mathrm{Se}\right), 2.55\left(\mathrm{t}, J=7.2 \mathrm{~Hz}, 4 \mathrm{H}, 2 \times \underline{\mathrm{CH}}_{2} \mathrm{Se}\right) ;{ }^{13} \mathrm{C}-\mathrm{NMR}\left(\mathrm{CDCl}_{3}, 100.4\right.$ $\mathrm{MHz}): \delta=13.22,23.12,23.25,33.13 ;{ }^{77} \mathrm{Se}-\mathrm{NMR}\left(\mathrm{CDCl}_{3}, 76.1 \mathrm{MHz}\right): \delta=160.20$.

$\boldsymbol{s}$-butyl $\boldsymbol{n}$-butyl selenide. ${ }^{18}$ Colorless liquid; $\mathrm{R}_{\mathrm{f}}=0.78$ (pentane $100 \%$ ); IR (neat, $\mathrm{cm}^{-1}$ ): 2961 , 2928, 2873, 1456, 1377, 1260, 1196, 1141, 1099, 991, 941, 895, 791, 741; ${ }^{1} \mathrm{H}-\mathrm{NMR}\left(\mathrm{CDCl}_{3}, 400\right.$ $\mathrm{MHz}): \delta=0.93\left(\mathrm{t}, J=7.3 \mathrm{~Hz}, 3 \mathrm{H}, \mathrm{CH}_{3}\left(\mathrm{CH}_{2}\right)_{2}\right), 0.99$ (t, $\left.J=7.4 \mathrm{~Hz}, 3 \mathrm{H}, \mathrm{CH}_{3} \mathrm{CH}_{2} \mathrm{CH}\right), 1.30-1.74$ $\left(\mathrm{m}, 9 \mathrm{H}, \mathrm{CH}_{3}\left(\mathrm{C}_{2}\right)_{2}\right.$ and $\mathrm{CH}_{3} \underline{\mathrm{C}}_{2} \mathrm{CHCH}_{3}(1 \mathrm{~d}$ at $\left.1.42,7.02 \mathrm{~Hz})\right), 2.57(\mathrm{t}, J=7.5 \mathrm{~Hz}, 2 \mathrm{H}$, $\left.\mathrm{CH}_{2} \mathrm{Se}\right), 2.91$ (sex, $\left.J=6.9 \mathrm{~Hz}, 1 \mathrm{H}, \mathrm{CHSe}\right) ;{ }^{77} \mathrm{Se}-\mathrm{NMR}\left(\mathrm{CDCl}_{3}, 76.1 \mathrm{MHz}\right): \delta=259.33$.

$\boldsymbol{t}$-butyl $\boldsymbol{n}$-butyl selenide. ${ }^{19}$ colorless liquid; $\mathrm{R}_{\mathrm{f}}=0.9$ (pentane $100 \%$ ); IR (neat, $\mathrm{cm}^{-1}$ ): 2959 , 2933, 2892, 2873, 2862, 1459, 1365, 1377, 1291, 1260, 1195, 1158, 1093, 1020, 897, 738; ${ }^{1} \mathrm{H}-$ $\operatorname{NMR}\left(\mathrm{CDCl}_{3}, 400 \mathrm{MHz}\right): \delta=0.93\left(\mathrm{t}, J=7.4 \mathrm{~Hz}, 3 \mathrm{H}, \mathrm{C}_{3} \mathrm{CH}_{2}\right), 1.40-1.47\left(\mathrm{~m}, 11 \mathrm{H},\left(\mathrm{C}_{3}\right)_{3} \mathrm{C}\right.$ (s at 1.46) and $\mathrm{CH}_{3} \underline{\mathrm{CH}}_{2}\left(J=7.4 \mathrm{~Hz}\right.$ ), 1.67 (quint, $J=7.4 \mathrm{~Hz}, 2 \mathrm{H}, \mathrm{CH}_{2} \mathrm{CH}_{2} \mathrm{Se}$ ), 2.61 (t, $J=7.4 \mathrm{~Hz}$, $\left.2 \mathrm{H}, \underline{\mathrm{CH}}_{2} \mathrm{Se}\right),{ }^{77} \mathrm{Se}-\mathrm{NMR}\left(\mathrm{CDCl}_{3}, 76.1 \mathrm{MHz}\right): \delta=376.21$.

General procedure for competition reactions involving alkyl phenyl selenides and a ten fold excess of butyllithiums (Scheme 4). A solution of alkyl phenyl selenide (1 mmol) in tetrahydrofuran $(1 \mathrm{~mL})$ is added dropwise at $-100^{\circ} \mathrm{C}$ under an atmosphere of argon, to a solution of $n$-butyllithium $(6.25 \mathrm{~mL}, 10 \mathrm{mmol}), s$-butyllithium $(7.14 \mathrm{~mL}, 10 \mathrm{mmol})$ and $t$-butyllithium $(5.88 \mathrm{~mL}, 10 \mathrm{mmol})$ in tetrahydrofuran $(4 \mathrm{~mL})$. The yellowish mixture is stirred at $-78^{\circ} \mathrm{C}$ for $1 \mathrm{~h}$ then quenched cautiously with methanol (Slow addition of $4 \mathrm{~mL}$ in $16 \mathrm{~min}$.) leading to a colorless solution. At that stage and depending on the reaction, the following procedures have been used: 
1) For methyl phenyl selenide and $\boldsymbol{n}$-butyl phenyl selenide. An internal standard (50 mg, tridecane) is then added to the resulting mixture. An aliquot is taken, diluted with diethyl ether (some drops), washed with water, dried with molecular sieves and analyzed by GC (program for methyl phenyl selenide: isotherm at $40^{\circ} \mathrm{C}$ for $10 \mathrm{~min}$. then $40^{\circ} \mathrm{C}$ to $220^{\circ} \mathrm{C}$ with a gradient of $10^{\circ} \mathrm{C} / \mathrm{min}$ and program for $n$-butyl phenyl selenide: $60^{\circ} \mathrm{C}$ to $220^{\circ} \mathrm{C}, 10^{\circ} \mathrm{C} / \mathrm{min}$ ). This allows the determination of yields of dialkylselenides. Spectroscopic data of the authentic compounds are described below:

n-butyl methyl selenide. ${ }^{17}$ volatile liquid; IR (neat, $\mathrm{cm}^{-1}$ ): 2958, 2927, 2872, 1462, 1425, 1379, 1257, 1201, 1094, 1049, 923, 902, 774, 738; ${ }^{1} \mathrm{H}-\mathrm{NMR}\left(\mathrm{CDCl}_{3}, 400 \mathrm{MHz}\right): \delta=0.93(\mathrm{t}, J=7.5$ $\left.\mathrm{Hz}, 3 \mathrm{H}, \mathrm{CH}_{3} \mathrm{CH}_{2}\right), 1.42\left(\mathrm{sex}, J=7.5 \mathrm{~Hz}, 2 \mathrm{H}, \mathrm{CH}_{3} \underline{\mathrm{CH}}_{2}\right), 1.66$ (quint, $J=7.5 \mathrm{~Hz}, 2 \mathrm{H}$, $\left.\mathrm{CH}_{2} \mathrm{CH}_{2} \mathrm{CH}_{2}\right), 2.00\left(\mathrm{~s}, 3 \mathrm{H}, \underline{\mathrm{CH}}_{3} \mathrm{Se}\right), 2.56\left(\mathrm{t}, J=7.5 \mathrm{~Hz}, 2 \mathrm{H}, \underline{\mathrm{CH}}_{2} \mathrm{Se}\right) ;{ }^{13} \mathrm{C}-\mathrm{NMR}\left(\mathrm{CDCl}_{3}, 100.4\right.$ $\mathrm{MHz}): \delta=3.81,13.51,22.85,25.12,32.24 ;{ }^{77} \mathrm{Se}-\mathrm{NMR}\left(\mathrm{CDCl}_{3}, 76.1 \mathrm{MHz}\right) \delta=76$.

$\boldsymbol{s}$-butyl methyl selenide. ${ }^{20}$ volatile liquid, ${ }^{1} \mathrm{H}-\mathrm{NMR}\left(\mathrm{CDCl}_{3}, 400 \mathrm{MHz}\right): \delta=0.99(\mathrm{t}, J=7.4 \mathrm{~Hz}, 3$ $\left.\mathrm{H}, \mathrm{C}_{3} \mathrm{CH}_{2}\right), 1.39$ (d, $\left.J=6.7 \mathrm{~Hz}, 3 \mathrm{H}, \mathrm{CH}_{3} \mathrm{CH}\right), 1.54-1.71\left(\mathrm{~m}, 2 \mathrm{H}, \mathrm{CH}_{3} \underline{\mathrm{CH}}_{2}\right), 1.96(\mathrm{~s}, 3 \mathrm{H}$, $\left.\mathrm{C}_{3} \mathrm{Se}\right), 2.83$ (sex, $\left.J=6.9 \mathrm{~Hz}, 1 \mathrm{H}, \mathrm{CH}_{3} \mathrm{CH}\right),{ }^{13} \mathrm{C}-\mathrm{NMR}\left(\mathrm{CDCl}_{3}, 100.4 \mathrm{MHz}\right): \delta=1.96,12.24$, 21.34, 30.28, 37.16; ${ }^{77} \mathrm{Se}-\mathrm{NMR}\left(\mathrm{CDCl}_{3}, 76.1 \mathrm{MHz}, \delta\right.$ in ppm): 171.71.

t-butyl methyl selenide. ${ }^{17}$ volatile liquid; IR (Neat, $\mathrm{cm}^{-1}$ ): 2964, 2931, 2893, 2861, 1457, 1425 , 1366, 1273, 1217, 1159, 1024, 896, 758, 668; ${ }^{1} \mathrm{H}-\mathrm{NMR}\left(\mathrm{CDCl}_{3}, 400 \mathrm{MHz}\right): \delta=1.44$ (s, $9 \mathrm{H}$, $\left.\left(\mathrm{CH}_{3}\right)_{3} \mathrm{C}\right), 1.98\left(\mathrm{~s}, 3 \mathrm{H}, \mathrm{CH}_{3} \mathrm{Se}\right) ;{ }^{13} \mathrm{C}-\mathrm{NMR}\left(\mathrm{CDCl}_{3}, 100.4 \mathrm{MHz}\right): \delta=1.66,31.69 ;{ }^{77} \mathrm{Se}-\mathrm{NMR}$ $\left(\mathrm{CDCl}_{3}, 76.1 \mathrm{MHz}\right): \delta=294.22$; GC-EIMS [m/z, (\%)] : $152\left(\mathrm{M}^{+}, 68\right), 137$ (5), 93 (29), 57 (100)

2) For $n$-decyl phenyl selenide. Water $(5 \mathrm{~mL})$ is added to the medium and the organic layer is separated. The aqueous layer is extracted with diethyl ether $(50 \mathrm{~mL}$ x 3$)$. The combined organic layers are washed with water $(5 \mathrm{~mL})$, dried over magnesium sulfate, filtrated and concentrated under reduced pressure with a rotary evaporator. The crude mixture is subjected to a bulb to bulb distillation $\left(80^{\circ} \mathrm{C}, 1 \mathrm{mmHg}\right)$. The non-distilled fraction contains the $s$-butyl $n$-decyl selenide and the $t$-butyl $n$-decyl selenide whose ratio are estimated by ${ }^{1} \mathrm{H}$ NMR and allows the yield determination. Spectroscopic data of the corresponding authentic compounds are described below:

n-decyl $s$-butyl selenide. yellow liquid; $R_{\mathrm{f}}=0.66$ (pentane $100 \%$ ); IR (neat, $\mathrm{cm}^{-1}$ ): 2959, 2926, 2854, 1457, 1377, 1347, 1290, 1273, 1199, 1141, 1042, 997, 954, 888, 837, 788, 721; ${ }^{1} \mathrm{H}-\mathrm{NMR}$ $\left(\mathrm{CDCl}_{3}, 400 \mathrm{MHz}\right): \delta=0.88\left(\mathrm{t}, J=7.0 \mathrm{~Hz}, 3 \mathrm{H}, \mathrm{CH}_{3} \mathrm{CH}_{2} \mathrm{CH}_{2}\right), 0.98(\mathrm{t}, J=7.1 \mathrm{~Hz}, 3 \mathrm{H}$, $\left.\mathrm{C}_{3} \mathrm{CH}_{2} \mathrm{CH}\right), 1.26-1.43\left(\mathrm{~m}, 17 \mathrm{H}, \mathrm{CH}_{3}\left(\mathrm{C}_{2}\right)_{7}\right.$ and $\left.\mathrm{C}_{3} \mathrm{CH}\right), 1.55-1.70\left(\mathrm{~m}, 4 \mathrm{H}, \mathrm{C}_{2} \mathrm{CH}_{2} \mathrm{Se}\right.$ and $\left.\mathrm{C}_{2} \mathrm{CH}\right), 2.55$ (t, $J=7.0 \mathrm{~Hz}, 2 \mathrm{H}, \underline{\mathrm{CH}}_{2} \mathrm{Se}$ ), 2.89 (sex, $\left.J=6.8 \mathrm{~Hz}, 1 \mathrm{H}, \mathrm{C} \underline{\mathrm{HSe}}\right) ;{ }^{13} \mathrm{C}-\mathrm{NMR}\left(\mathrm{CDCl}_{3}\right.$, $100.4 \mathrm{MHz}): \delta=12.22,14.02,21.88,22.61,29.12,29.24,29.46,30.07,30.77,31.83,36.52 ;{ }^{77} \mathrm{Se}$ NMR $\left(\mathrm{CDCl}_{3}, 76.1 \mathrm{MHz}\right) \delta=259.31$; GC-EIMS [m/z, (\%)]: $278\left(\mathrm{M}^{+}, 8\right), 221(10), 140(4), 112$ (2), 97 (7), 85 (20), 71 (22), 57 (100); Anal. Calcd for $\mathrm{C}_{14} \mathrm{H}_{30} \mathrm{Se}$ : C, 60.63; H, 10.90; Found: C, $60.52 ; \mathrm{H}, 10.86$.

n-decyl $\boldsymbol{t}$-butyl selenide. ${ }^{19}$ colorless liquid; $\mathrm{R}_{\mathrm{f}}=0.53$ (pentane $100 \%$ ); IR (neat, $\mathrm{cm}^{-1}$ ): 2958 , 2926, 2855, 1459, 1376, 1365, 1299, 1269, 1241, 1217, 1158, 1021, 721; ${ }^{1} \mathrm{H}-\mathrm{NMR}\left(\mathrm{CDCl}_{3}, 400\right.$ $\mathrm{MHz}): \delta=0.87\left(\mathrm{t}, J=7.4 \mathrm{~Hz}, 3 \mathrm{H}, \mathrm{C}_{3} \mathrm{CH}_{2}\right), 1.26-1.30\left(\mathrm{~m}, 14 \mathrm{H}, \mathrm{CH}_{3}\left(\mathrm{CH}_{2}\right)_{7}\right), 1.44(\mathrm{~s}, 9 \mathrm{H}$, 
$\left(\underline{\mathrm{CH}}_{3}\right)_{3} \mathrm{C}$ ), 1.66 (quint, $J=7.4 \mathrm{~Hz}, 2 \mathrm{H}, \mathrm{C}_{2} \mathrm{CH}_{2} \mathrm{Se}$ ), 2.58 (t, $J=7.4 \mathrm{~Hz}, 2 \mathrm{H}, \mathrm{CH}_{2} \mathrm{Se}$ ); ${ }^{13} \mathrm{C}-\mathrm{NMR}$ $\left(\mathrm{CDCl}_{3}, 100.4 \mathrm{MHz}\right): \delta=14.00,21.96,22.59,29.14,29.22,29.47,30.25,30.63,31.82,32.48$, $38.26 ;{ }^{77} \mathrm{Se}-\mathrm{NMR}\left(\mathrm{CDCl}_{3}, 76.1 \mathrm{MHz}\right): \delta=376.58$.

General procedure for competition reactions involving a five fold excess of methyl aryl or phenyl selenides and butyllithium (Scheme 6)

$n$-Butyllithium in hexanes $(1.03 \mathrm{mmol})$ is added dropwise, at $-78^{\circ} \mathrm{C}$ under an atmosphere of argon, to a stirred solution of methyl phenyl selenide $(5 \mathrm{mmol})$ and methyl aryl selenide (5 mmol) in tetrahydrofuran $(5 \mathrm{~mL})$. The mixture is stirred at $-78^{\circ} \mathrm{C}$ for $1 \mathrm{~h}$, then quenched with methanol $(2 \mathrm{~mL})$. At that stage the crude mixture is analyzed by GC (using two typ of conditions involving two internal standards) to determine the yields of the arenes as well as of $n$-butyl methyl selenide.

(a) Determination of the arenes: An internal standard ( $n$-heptane, $30 \mathrm{mg}$ ), is added to the mixture. An aliquot is removed, diluted with diethyl ether (few drops), washed with water, dried with molecular sieves and analyzed by GC on a AT-Q heliflex column (isotherm at $170^{\circ} \mathrm{C}$ for $13 \mathrm{~min}$ and then $170^{\circ} \mathrm{C}$ to $230^{\circ} \mathrm{C}$ with a gradient of $20^{\circ} \mathrm{C} / \mathrm{min}$ ).

(b) Determination of the $n$-butyl methyl selenide: An internal standard (tridecane, $50 \mathrm{mg}$ ) is added to the mixture. Another aliquot is taken, diluted with diethyl ether (few drops), washed with water, dried with molecular sieves and analyzed by GC on a RSL-150 column (isotherm at $40^{\circ} \mathrm{C}$ for $10 \mathrm{~min}$. then $40^{\circ} \mathrm{C}$ to $220^{\circ} \mathrm{C}$ with a gradient of $\left.10^{\circ} \mathrm{C} / \mathrm{min}\right)$.

\section{General procedure for the alkylation of aryllithiums (Scheme 7)}

A solution of $s$-butyllithium $(0.73 \mathrm{~mL}, 1.03 \mathrm{mmol})$ in cyclohexane is added dropwise at $-78^{\circ} \mathrm{C}$ under an atmosphere of argon, to a stirred solution of methyl aryl selenide $(1 \mathrm{mmol})$ in tetrahydrofuran $(1 \mathrm{~mL})$. The resulting solution is then stirred at $-78^{\circ} \mathrm{C}$ for an additional hour. then 1-bromo-decane $(232 \mathrm{mg}, 1.05 \mathrm{mmol})$ in tetrahydrofuran $(1 \mathrm{~mL})$ is added dropwise to the reaction medium at that temperature.* The resulting mixture is stirred at $0{ }^{\circ} \mathrm{C}$ for a time $2 \mathrm{~h}$, left overnight, then quenched with methanol $(2 \mathrm{~mL})$. Water $(5 \mathrm{~mL})$ is added and the organic layer is separated. The aqueous layer is extracted with diethyl ether $(3 \times 50 \mathrm{~mL})$. The combined organic layer are washed with water $(5 \mathrm{~mL})$, dried over magnesium sulfate, filtrated and concentrated under reduced pressure with a rotary evaporator. The purification of the crude mixtures are described below:

* In the case of methyl trifluoromethylphenylselenide, HMPA in THF is added at that stage (1mmol in $1 \mathrm{~mL})$.

1-n-décyl-3-methoxy-benzene. Purified by preparative thick layer chromatography on silica gel eluted with pentane $(100 \%), \mathrm{R}_{\mathrm{f}}=0.28$; yield: $73 \%(180 \mathrm{mg})$. Colorless liquid. IR (neat, $\left.\mathrm{cm}^{-1}\right)$ : 3029, 2998, 2955, 2927, 2854, 1917, 1831, 1731, 1602, 1586, 1489, 1465, 1437, 1377, 1313, 1261, 1190, 1164, 1153, 1047, 996, 910, 873, 851, 775, 738, 723, 694; ${ }^{1} \mathrm{H}-\mathrm{NMR}\left(\mathrm{CDCl}_{3}, 400\right.$ $\mathrm{MHz}$ ): $\delta=0.87\left(\mathrm{t}, J=7.3 \mathrm{~Hz}, 3 \mathrm{H}, \mathrm{C}_{3} \mathrm{CH}_{2}\right), 1.25-1.30\left(\mathrm{~m}, 14 \mathrm{H}, \mathrm{CH}_{3}\left(\mathrm{C}_{2}\right)_{7}\right), 1.60$ (quint, $J=$ $7.3 \mathrm{~Hz}, 2 \mathrm{H}, \mathrm{CH}_{2} \mathrm{CH}_{2} \mathrm{Ar}$ ), 2.57 (t, $J=7.3 \mathrm{~Hz}, 2 \mathrm{H}, \mathrm{CH}_{2} \mathrm{CH}_{2} \mathrm{Ar}$ ), 3.80 (s, $3 \mathrm{H}, \mathrm{CH}_{3} \mathrm{O}$ ), 6.72-6.79 (m, $3 \mathrm{H}, \mathrm{Ar}), 7.19$ (m, $1 \mathrm{H}, \mathrm{Ar}) ;{ }^{13} \mathrm{C}-\mathrm{NMR}\left(\mathrm{CDCl}_{3}, 100.4 \mathrm{MHz}\right): \delta=14.02,22.61,29.28,29.46$, 29.53, 31.35, 31.83, 35.99, 55.04, 110.81, 114.21, 120.89, 129.17, 144.70, 159.64; GC-EIMS 
[m/z, (\%)]: $248\left(\mathrm{M}^{+}\right), 122,107,91,77$; Anal. Calcd for $\mathrm{C}_{17} \mathrm{H}_{28} \mathrm{O}$ : C, 82.20; H, 11.36; Found: C, 82.57; H, 11.51 .

1-decyl-4-methoxy-benzene. ${ }^{21}$ Purified by preparative thick layer chromatography on silica gel eluted with pentane $(100 \%), \mathrm{R}_{\mathrm{f}}=0.30$; yield: $70 \%(174 \mathrm{mg})$. Yellow liquid. IR (neat, $\left.\mathrm{cm}^{-1}\right)$ : 3063, 3031, 2998, 2955, 2927, 2854, 1613, 1585, 1513, 1465, 1443, 1377, 1300, 1246, 1178, $1117,1040,822,807,749,722,698 ;{ }^{1} \mathrm{H}-\mathrm{NMR}\left(\mathrm{CDCl}_{3}, 400 \mathrm{MHz}\right): \delta=0.88(\mathrm{t}, J=7.2 \mathrm{~Hz}, 3 \mathrm{H}$, $\left.\mathrm{CH}_{3} \mathrm{CH}_{2}\right), 1.26-1.30\left(\mathrm{~m}, 14 \mathrm{H}, \mathrm{CH}_{3}\left(\mathrm{CH}_{2}\right)_{7}\right), 1.57$ (quint, $J=7.2 \mathrm{~Hz}, 2 \mathrm{H}, \mathrm{CH}_{2} \mathrm{CH}_{2} \mathrm{Ar}$ ), 2.54 (t, $J=$ $\left.7.2 \mathrm{~Hz}, 2 \mathrm{H}, \mathrm{CH}_{2} \mathrm{CH}_{2} \mathrm{Ar}\right), 3.79$ (s, $3 \mathrm{H}, \mathrm{CH}_{3} \mathrm{O}$ ), 6.82 (m, $\left.2 \mathrm{H}, \mathrm{Ar}\right), 7.09$ (m, $\left.2 \mathrm{H}, \mathrm{Ar}\right) ;{ }^{13} \mathrm{C}-\mathrm{NMR}$ $\left(\mathrm{CDCl}_{3}, 100.4 \mathrm{MHz}\right): \delta=14.04,22.60,29.23,29.27,29.46,29.56,31.71,31.83,34.98,55.19$, 113.65, 129.28, 135.13, 157.65. Anal. Calcd for $\mathrm{C}_{17} \mathrm{H}_{28} \mathrm{O}$ : C, 82.20; H, 11.36; Found: C, 82.57; H, 11.51 .

1-decyl-4-dimethylamino-benzene. ${ }^{22}$ Purified by column chromatography on silica gel eluted with pentane/diethyl ether (95/5); TLC $\mathrm{R}_{\mathrm{f}}=0.46$ (pentane/diethyl ether: 95/5). Yellow liquid. IR (neat, $\mathrm{cm}^{-1}$ ): 3095, 3009, 2955, 2925, 2854, 2798, 1617, 1566, 1522, 1464, 1344, 1222, 1191, $1163,1132,1060,948,806,759,722,673 ;{ }^{1} \mathrm{H}-\mathrm{NMR}\left(\mathrm{CDCl}_{3}, 400 \mathrm{MHz}\right): \delta=0.87(\mathrm{t}, J=7.2 \mathrm{~Hz}$, $3 \mathrm{H}, \underline{\mathrm{CH}}_{3} \mathrm{CH}_{2}$ ), 1.25-1.30 (m, $\left.14 \mathrm{H}, \mathrm{CH}_{3}\left(\mathrm{C}_{2}\right)_{7}\right), 1.56$ (quint, $J=7.2 \mathrm{~Hz}, 2 \mathrm{H}, \mathrm{C}_{2} \mathrm{CH}_{2} \mathrm{Ar}$ ), 2.51 (t, $\left.J=7.2 \mathrm{~Hz}, 2 \mathrm{H}, \mathrm{CH}_{2} \mathrm{CH}_{2} \mathrm{Ar}\right), 2.93\left(\mathrm{~s}, 6 \mathrm{H},\left(\mathrm{CH}_{3}\right)_{2} \mathrm{~N}\right), 6.76(\mathrm{~m}, 2 \mathrm{H}, \mathrm{Ar}), 7.26(\mathrm{~m}, 2 \mathrm{H}, \mathrm{Ar})$; ${ }^{13} \mathrm{C}-\mathrm{NMR}\left(\mathrm{CDCl}_{3}, 100.4 \mathrm{MHz}\right): \delta=14.06,22.63,29.29,29.52,29.56,31.77,31.85,34.87$, 41.09, 113.21, 129.03, 135.90, 148.76 .

1-decyl-4-trifluoromethyl-benzene. Bromo decane is separated by bulb to bulb distillation and the residue is purified by preparative thick layer chromatography on silica gel eluted with pentane $(100 \%), \mathrm{R}_{\mathrm{f}}=0.9$; yield: $70 \%(174 \mathrm{mg})$.Yellow liquid. IR (neat, $\left.\mathrm{cm}^{-1}\right): 2928,2857$, $1620,1465,1418,1327,1165,1127,1069,1020,843,820,723,632,612 ;{ }^{1} \mathrm{H}-\mathrm{NMR}\left(\mathrm{CDCl}_{3}\right.$, $400 \mathrm{MHz}$ ): $\delta=0.88\left(\mathrm{t}, J=7.3 \mathrm{~Hz}, 3 \mathrm{H}, \mathrm{C}_{3} \mathrm{CH}_{2}\right), 1.25-1.31\left(\mathrm{~m}, 14 \mathrm{H}, \mathrm{CH}_{3}\left(\mathrm{C}_{2}\right)_{7}\right), 1.60$ (quint, $\left.J=7.3 \mathrm{~Hz}, 2 \mathrm{H}, \mathrm{C}_{2} \mathrm{CH}_{2} \mathrm{Ar}\right), 2.65$ (t, $J=7.3 \mathrm{~Hz}, 2 \mathrm{H}, \mathrm{CH}_{2} \underline{\mathrm{C}}_{2} \mathrm{Ar}$ ), 7.27 (m, $\left.2 \mathrm{H}, \mathrm{Ar}\right), 7.52$ (m, 2 $\mathrm{H}, \mathrm{Ar}) ;{ }^{13} \mathrm{C}-\mathrm{NMR}\left(\mathrm{CDCl}_{3}, 100.4 \mathrm{MHz}\right): \delta=14.01,22.60,29.15,29.26,29.39,29.50,29.52$, $31.15,31.84,35.74,125.19,128.72,147.11$.

\section{References}

1. (a) Wakefield, B. J. In The Chemistry of Organolithium Compounds Pergamon; Oxford, 1974. (b) Wakefield, B. J. In Organolithium Methods Academic Press: London, 1988. (c) Clayden, J. In Organolithiums : Selectivity For Synthesis Elsevier Science : Oxford, 2002. (d) Gray, M.; Tinkl, M.; Snieckus, V. In Comprehensive Organometallic Chemistry Abel, E. W.; Stone, G. A.; Wilkinson, G.; Eds.; Pergamon Press: Oxford, 1995; Vol. 11, p 1. (e) Schlosser, M. In Organometallics in Synthesis: A Manual Schlosser, M.; Ed.; Wiley : New York: 2002, p 1. (f) Leroux F.; Schlosser, M.; Zohar, E.; Marek, I. In The Chemistry of Organolithium Compounds (Part 1), Rappoport, Z.; Marek, I.; Eds., Wiley: Chichester, 2004, p 435. (g) Yus, M.; Foubelo, F. In Handbook of Functionalized Organometallics 
Knochel, P., Ed; Wiley-VCH : Weinheim, 2005, p 7. (h) Huryn, D. M. In Comprehensive Organic Synthesis Schreiber, S. L.; Vol. Ed.; Trost, B. M.; Fleming, I. Eds., Pergamon Press: Oxford, 1991; Vol 1 p 49.

2. (a) Lindsell, W. E. In Comprehensive Organometallic Chemistry Abel, E. W.; Stone, G. A.; Wilkinson, G.; Eds.; Pergamon Press: Oxford, 1995; Vol. 1, p 58. (b) Wakefield, B. In Organomagnesium Methods In Organic Chemistry Academic Press: San Diego, 1995. (c) Knochel, P.; Krasovskly, A.; Sapountzis, I. In Handbook of Functionalized Organometallics Knochel, P.; Ed.; Wiley-VCH : Weinheim, 2005, p 109.

3. (a) Gilman, H.; Bebb, R. L. J. Am. Chem. Soc. 1939, 61, 109. (b) Gilman, H.; Webb, F. J. J. Am. Chem. Soc. 1949, 71, 4062.

4. Dumont, W.; Bayet, P.; Krief, A. Angew. Chem. Int. Ed. 1974, 13, 805.

5. (a) Seebach, D.; Peleties, N. Angew. Chem. Int. Ed. 1969, 8, 450. (b) Seebach, D.; Peleties, N. Chem. Ber. 1972, 105, 511.

6. (a) Krief, A. Tetrahedron 1980, 36, 2531. (b) Krief, A. In The Chemistry of Organic Selenium and Tellurium Compounds 1987, Vol. 2, p 675. (c) Krief, A.; Dumont, W.; Clarembeau, M.; Badaoui, E. Tetrahedron 1989, 45, 2005. (d) Krief, A.; Dumont, W.; Clarembeau, M.; Badaoui, E. Tetrahedron 1989, 45, 2023. (e) Krief, A. In Comprehensive Organometal Chem. II 1995, Vol 11, p 515.

7. Van Ende, D.; Cravador, A.; Krief, A. J. Organomet. Chem. 1979, 177, 1.

8. (a) Dumont, W.; Krief, A. Angew. Chem. Int. Ed. 1976, 15, 161. (b) Halazy, S.; Dumont, W.; Krief, A. Tetrahedron Lett. 1981, 22, 4737.

9. Clarembeau, M.; Krief, A. Tetrahedron Lett. 1984, 25, 3629.

10. (a) Clarembeau, M.; Krief, A. Tetrahedron Lett. 1985, 26, 1093. (b) Krief, A.; Clarembeau, M.; Barbeaux, P. J. Chem. Soc., Chem. Commun. 1986, 457.

11. Sevrin, M.; Denis, J. N.; Krief, A. Angew. Chem. Int. Ed. Engl. 1978, 17, 56.

12. (a) Wittig, G.; Fuhrman, G. Chem. Ber. 1940, 73, 1197. (b) Gschwend, H. W.; Rodriguez, H. R Org. Reac. 1979, 26, 1. (c) Beak, P.; Brown, R. A. J. Org. Chem. 1982, 47, 34. (d) Nakatani, M.; Nakamura, M.; Suzuki, A.; Fuchikami, T.; Inoue, M.; Katoh, ARKIVOC 2003, (viii), 45. (e) Reich, H. J.; Goldenberg, W. S.; Sanders, A. W. ARKIVOC 2004, (xiii), 97. (f) Najera, C.; Sansano, J. M.; Yus, M. Tetrahedron 2003, 59, 9255. (g) Guijarro, D.; Yus, M. Tetrahedron 2000, 56, 1135.

13. (a) Merill, R. E.; Neghishi, E.-I. J. Org. Chem.1974, 39, 3453. (b) Gilman, H.; Moore, F. W. J. Am. Chem. Soc. 1940, 62, 1843. (c) Gilman, H.; Jones, R. G. J. Am. Chem. Soc. 1941, 63, 1441. (d) For an alternative method: Neuman, H.; Seebach, D. Chem. Ber. 1978, 111, 2785. and Solorio-Alvarado, C. R.; Pena-Cabrer, E. ARKIVOC 2004, (i), 64.

14. Suffert, J. J. Org. Chem. 1989, 54, 509.

15. Nishiyama, Y.; Tokunaga, K.; Sonoda, N. Org. Lett. 1999, 1, 1725.

16. Brindaban C. R., Tanmay M., Sampak S. Org. Lett. 2003, 5, 1439.

17. Klapötke, T. M.; Broschag, M. Compilation of reported Se ${ }^{77}$ NMR chemical shifts; Wiley and Sons Ltd.: West Sussex, 1996. 
18. Arase, A.; Masuda, Y. Chem. Lett. 1975, 5, 419

19. Krief, A.; Derock, M.; Lacroix, D. Synlett 2005, 18, 2832.

20. Ohno, K. Bull. Chem. Soc. Jpn 1977, 50, 305.

21. Herve, A.; Rodriguez, A. L.; Fouquet, J. Org. Chem. 2005, 70, 1953.

22. Douvres, F. W.; Thompson, M. J.; Robbins, W. Veterinary Parasitology 1980, 7, 195. 